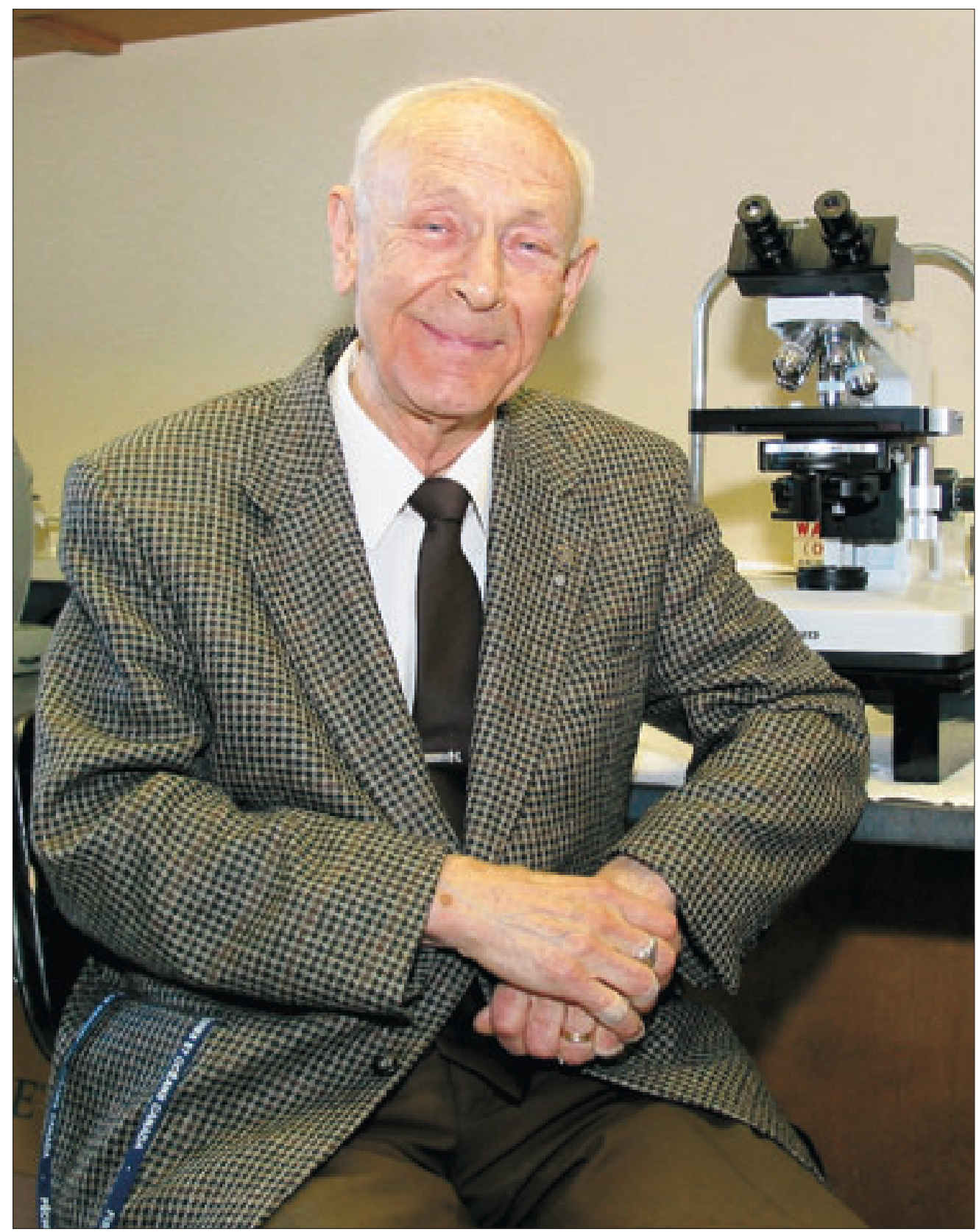

EIGHTY YEARS OF EXCELLENCE: Prof. Dr ZBIGNIEW KABATA 



\title{
EIGHTY YEARS OF EXCELLENCE: DR ZBIGNIEW KABATA
}

by

\author{
George W. BENZ1, Wojciech PIASECKI ${ }^{2}$
}

${ }^{1}$ Department of Biology, Middle Tennessee State University, P.O. Box 60, Murfreesboro, Tennessee, USA 37132.e-mail: gbenz@mtsu.edu

${ }^{2}$ Faculty of Food Sciences and Fisheries, Agricultural University of Szczecin, Szczecin,

Poland.e-mail: piasecki@fish.ar.szczecin.pl

It is with great happiness that we extend warmest good wishes to Dr Zbigniew (Bob) Kabata and announce his recent 80th birthday on 17 March 2004. An important dignitary of the Editorial Advisory Board of Acta Ichthyologica et Piscatoria, Dr Kabata's expertise in parasitology is legendary and his guidance and goodwill are greatly appreciated.

We also beam in announcing that on 2 August 2003, the American Society of Parasitologists (ASP) honored Dr Kabata by bestowing upon him the Eminent Parasitologist Award at the Society's 78th Annual Meeting held in Halifax, Canada. Not reserved for ASP members, the Eminent Parasitologist Award is bestowed on a bi-annual basis for a substantial contribution to parasitology over a long period. Dr Kabata could not attend the meeting, but those in attendance heard introductory remarks by Dr Timothy Goater (Appendix 1) and then a video-taped acceptance speech by Dr Kabata (Appendix 2) that demonstrated his obsession with parasitic copepods.

Few leaders are as inspirational as Dr Kabata, and his influence on the field of parasitology is profoundly significant and only surpassed by his comradeship and goodwill towards colleagues, students, and others. With this in mind, we thought it fitting to share his acceptance speech with the readership, prefaced by the introductory remarks made by Dr Goater at the recent ASP meeting.

Readers wishing to learn more about Dr Kabata might avail themselves to an article published in Acta Ichthyologica et Piscatoria (Anonymous 1993) that featured speeches made at the conferral of Dr Kabata's honorary doctorate by the University of Agriculture in Szczecin, a list of his publications, and a list of scientific taxa named in his honor (these lists are now somewhat dated but still useful). As alluded to by $\mathrm{Dr}$ Goater in his opening ceremonial remarks (see below), Dr Kabata's recent acceptance of ASP's Eminent Parasitologist Award is just one of a long list of awards and distinctions that he has received since 1993. Students and educators will be especially interested to learn that Dr Kabata was also selected as the first personality featured in 
a video series focusing on most-influential fisheries scientists. Kabata: Evolution of a Scientist (Langley 2001) is a 29-minute video produced and distributed by the First Fisheries Science Documentary Society, and it traces Dr Kabata's rich human journey from wartime Poland, to Aberdeen, Scotland, and eventually to the Pacific Biological Station on the west coast of Canada.

\section{ACKNOWLEDGEMENTS}

Judith M. Benz is thanked for transcribing Dr Kabata's speech from a taped copy of the presentation kindly provided by Dr Timothy M. Goater (Malaspina UniversityCollege); however, we bear full responsibility for any lapsus introduced into the printed version of the presentation. We also thank Dr Goater for allowing us to print his introductory remarks, and John Lund (Malaspina University-College) for use of the photograph.

\section{REFERENCES}

Anonymous, 1993. Ceremony of conferral of the honorary doctorate upon Professor Zbigniew Kabata, Ph.D. by the Academy of Agriculture in Szczecin as requested by the Faculty of Marine Fisheries and Food Technology. Acta Ichthyologica et Piscatoria 23 (2): 1-18.

Langley R., (producer) 2001. Kabata: evolution of a scientist. First Fisheries Science Documentary Society. (29-minute video-film).

\section{Appendix 1}

"Introduction of Zbigniew Kabata as the 2003 recipient of the Eminent Parasitologist Award of the American Society of Parasitologists" by Timothy M. Goater, Biology Department, Malaspina University-College, Nanaimo, British Columbia, Canada

Heroic freedom fighter, deep-sea fisherman, award-winning scholar, famous author and poet, inspirational leader, influential and outstandingly productive scientist, generous mentor, highest honors citizen, humble gentleman and steadfast friend-these are a few of the achievements and superlatives that apply to the person we honor today.

It is my privilege, along with my co-nominator George Benz, to introduce Dr Zbigniew (Bob) Kabata as the recipient of one of our Society's most prestigious recognitions - the Eminent Parasitologist Award. This award "honors someone of eminence and international visibility for their substantial contributions to parasitology." I am proud to introduce a truly eminent parasitologist—Bob Kabata.

Before summarizing his parasitological fame, some history is in order so that people are aware of his remarkable life and his other accomplishments. Bob Kabata was born in Poland in 1924. At the age of 13, young Kabata entered a military academy in eastern Poland. From the ages of 16 to 21, he fought along with other partisans in a vicious clandestine war against the Nazis. The unit he served in became legendary in Poland and Kabata himself was cited several times for bravery. During this time in the 
underground war for freedom he wrote several poems honoring the army of the resistance. His most famous poem (written years later in 1964) would become an unofficial anthem of the combatant community in Poland. Today, this same poem appears on memorials and plaques throughout public places in Poland. In 1996, Dr Kabata was awarded one of Poland's highest decorations, the Grand Commander Cross of Polonia Restituta for his scientific accomplishments and for his outstanding war record. In 2002 he was the first-ever recipient of the Immigrant Achievement Award from the Canadian Bar Association, Immigration Branch. In 2002 he also was honored with an Honorary Doctor of Letters degree from my institution, Malaspina University-College, in his hometown of Nanaimo, British Columbia.

In 1945 Kabata pulled off a hair-raising escape and ended up in Italy. When Italy signed the peace treaty with the allies, the Polish 2 Army Corps (the unit in which he served) was moved to England. He then went on to become a North Sea fisherman and it was here, on the decks of fishing boats that he developed and nurtured a passion for science. He went on to become a brilliant student and graduated top of his class with his doctorate degree from the University of Aberdeen in Scotland.

Dr Kabata's parasitological eminence is exceptional for several reasons. First and foremost, Bob Kabata developed a life-long passion and infectious enthusiasm for parasitic copepods. He states, "Parasitic copepods present a floating laboratory for studying the evolution of parasitism. Probably no other group of parasites offers such a wide range of adaptation to parasitism and concomitant range of morphological transformation." As a parasitologist, he is perhaps most famous for his outstanding original research papers and books describing the morphology, life history, and development of these marvelously intricate animals. He is widely acknowledged as the foremost world expert in the field of parasitic copepod biology and systematics. He is a deeply respected mentor for the new generation of researchers in copepod parasitology. His long time Australian colleague, Bob Lester states, "The exceptional standard of his papers maintained over 50 years since his classic work on Lernaeocera in the 1950's can be equaled by few parasitologists. " Indeed, as a testament to the huge impact he has had on the field internationally, a total of 20 taxa (mostly copepods, but also including helminths and Myxozoa) from 15 countries carry his name! David Damkaer further stresses his systematic contributions by stating, "His own fundamental work on parasitic copepods has added 23 new genera and hundreds of new species to the known diversity of this interesting and significant animal group. " Respect for his meticulous systematic work (as well as his command of Greek and Latin!) earned him a 15-year stint as a Commissioner on the International Commission on Zoological Nomenclature.

One of his students, George Benz states, "It would de difficult to overstate Dr Kabata's contributions to parasitology and copepodology. An intellectual leader for contemporary copepodologists, Dr Kabata is the most influential and significant copepodologist of the 20th century. His publications have liberated the study of copepods from the dark ages through the genesis of a modern systematic foundation 
based on a deeply insightful understanding of biology and homology... insight gained through painstaking microscopic examination of thousands of copepods. The "Yoda" of copepodology, Kabata's science is brilliant, and it will forever serve as bedrock for the foundation of copepod research." As further evidence of his international stature, Dr Kabata was elected founding president of the World Association of Copepodologists in 1984, a position he held until his "retirement" in 1989.

In the view of many, his pivotal book Parasitic Copepoda of British Fishes represents a landmark publication in parasitology. The book is fantastic for its scope, with over 2000 illustrations of his beloved copepods hand-drawn in meticulous detail. One need only turn to the "crustaceans" chapter of current general parasitology and invertebrate zoology texts to see several of his beautiful illustrations in all of their bizarre morphological complexity. He is currently completing another book, one that will represent a fascinating and phenomenal synthesis of the biology of parasitic copepods and the complex interactions with the environment and their hosts. It is destined to be a parasitological and zoological classic.

There is a second reason why he deserves the title of eminent parasitologist. His groundbreaking research interests cover both basic and applied problems in fisheries parasitology. He is without a doubt one of the world's foremost fish parasitologists. Bob Kabata is famous in fisheries science as a pioneer in the use of parasites as biological tags, and for his ecosystem approach to managing fisheries. He was among the first to demonstrate that parasites could be valuable in identification and discrimination of commercially important marine fish stocks and in making vital fisheries management decisions. It was this research that brought him (in 1966) to the Pacific Biological Station on the west coast of Canada to work with his esteemed friend, Leo Margolis, on the use of parasites as biological tags in managing the fisheries resources. Together this duo of world-class scientists would bring international attention to the Pacific Biological Station. He also became famous in fisheries parasitology for his research papers and books demonstrating the economic impact of copepod parasitism on marine fish populations.

Yet another contribution was his translation of Russian parasitology literature. $\mathrm{He}$ made available the literature of Dogiel and other Russian authors to a new generation of parasitologists. His long-time colleague, Geoffrey Boxshall states, "I was brought up on these Russian works and depended heavily on the fruits of Kabata's work in my early years. This was a unique contribution to parasitology."

$\mathrm{He}$ is the recipient of several parasitology awards including the Wardle Medal from the Canadian Society of Zoologists and the Janicki Medal from the Polish Parasitological Society. Bob Kabata has served on the editorial boards of several journals, including Journal of Parasitology, Acta Parasitologica, and Systematic Parasitology. His role as referee for these journals is legendary. The Editor-in-Chief of this latter journal, David Gibson, says, "Bob's refereeing reflects the meticulous nature of all of his work - he is still today enormously helpful as a referee and always 
signs his reports." His international parasitological fame was further recognized recently when he was designated as honorary president of the Tenth International Congress of Parasitology held in Vancouver in 2002.

Bob Kabata is a deeply thoughtful, humble, and wise person who loves to share his experiences. Not only is he a mentor and role model to the upcoming generation of young scientists, but he enriches the lives of everyone he meets. I wish to share a personal story that reflects this. During his convocation speech, when he received his honorary doctorate degree from my institution, he turned around from the podium and spoke with his characteristic smile directly to the graduates. He then read several lines (without notes!) from Kipling's famous poem "If" encouraging the graduating class to follow their dreams. Many commented to me afterwards that it was the most inspirational speech they had every heard. It was clear to everyone that afternoon that Bob Kabata is far more than a famous parasitologist.

Bob Kabata is indeed a parasitological giant and an exceptional person, someone we should all be proud to have among our ranks. I am honored to present the recipient of the Eminent Parasitologist Award for 2003, my special friend and mentor- Dr Bob Kabata.

\section{Appendix 1}

\section{Eminent Parasitologist Address: "My life with parasites" by Zbigniew Kabata} Pacific Biological Station, Nanaimo, British Columbia, Canada

Mister chairman, colleagues and comrades and parasitologists at arms, ladies and gentlemen - it is with profound regret that I am forced by circumstances beyond my control to appear before you as a flickering shadow upon a screen rather than a warm body. However, things are not always as we wish them to be, and I am grateful to you for summoning me to appear before you at all. To appear as a parasitologist, before parasitologists.

Believe me, the fact that you accorded me the title of parasitologist, means to me more than an adjective to which you favor to have appended to this title. Having dealt with parasites for almost half a century, I am at last being recognized as a member of the honorable guild of parasitologists. When I think of this, there comes to me a distant echo, when a now legendary description of the parasitologist was first formulated by an unforgettable Asa Chandler in 1946. To quote: "I might compare a parasitologist to an orchid. He requires long and careful nurturing, he develops slowly, and, he is himself a parasite in that he is dependent on many other sciences for material aid. But when he comes to flower he is a rare and beautiful object, scientifically speaking, and is usually slow in going to seed. He may not always smell like an orchid, but we can't have everything."

He develops slowly. Indeed. When I think of my own development, I am very conscious of the fact that the early stages in my life were spent dealing not with 
parasites, but rather with predators. They wore steel helmets and carried submachine guns. One had to be swift of limb and mind to avoid becoming prey. What is more, one had to possess this indefinable gift known as luck. The fact that I have emerged from that period of my life with minimal structural damage is an ample proof that I do have this gift. At the end of this predatory period of my life, I was an accomplished machine-gunner and, I wasn't a bad hand with a combat knife either. But these were not very marketable skills when the theatre closed. Life demanded to be filled with something more constructive. Transformation of a redundant warrior into a parasitologist required an extensive and complicated metamorphosis as you might well imagine. The course of it will be presented to you in a few minutes. For now, let it suffice that I became a devotee of parasitic Copepoda.

Why Copepoda? Has any one of you asked yourself the question, why parasitology? It reminds me of ICOPA II in Washington DC in 1970. One of my local colleagues there, the late Roger Cressey, invited to his home to dinner all copepodologists present at the conference. There were about a dozen of us, among more than 2000 delegates present. Other than the Americans, among whom the most distinguished was the late Arthur Humes, there was Gordon Hewitt from New Zealand, Yves Carton from France, Paul Heegaard from Denmark, and from what used to be the USSR there was the late Markevich. As we sat around the table, Roger asked us a question: "What made you become a copepodologist?" With the sole exception of Heegaard, all of us had to say, "an accident." Well, I am quite sure that given a similar question, most of you there, dear colleagues, would probably answer in the same way, regardless of the branch or brand of your parasitology.

The biological and morphological variety of delicate structures of the copepods is something which will never cease to amaze even the casual observer. Look, for example, at how the copepods maintain themselves in contact with their host fish. The abominable sea lice of the family Caligidae developed a clinging sucker from their anterior end, from the cephalothorax. By expelling water from underneath, and by admitting controlled amounts of water from the anterior part, these copepods can expel water posteriorly in the form of jets that propel them forwards. Jet propulsion!

What about the frontal filament? A structure which for many copepods creates a lifeline and under the protection of which they can very easily scrap all of their larval structures and build up a new set of adult organs while swinging placidly at the end of the tether. Some of those copepods change their way of being attached to the host as many as five times in the course of their life. For example, I'll give you Schistobrachia ramosa of the Lernaeopodidae. It's an animal which when in first contact with the fish grabs it with the second antennae - first method — and then digs out a small cavity in the surface of the fish, plants in it the distal bulb of the filament, before letting go with its antennae, and now resting quietly, undergoing morphogenesis while swinging from the frontal filamentlevel 2. At the end of that period, when reaching the subadult stage, it relinquishes the filament and grabs the fish again with its second antennae — third method — and excavates 
another cavity in the surface of the fish, in which it deposits the most extraordinary organ that one can ever imagine... the bulla. Produced in the frontal region of the copepod, the bulla is placed into the cavity, glued into it with a special secretion of the maxillary glands. Then the second maxillae get attached to it and elongate to form a tether from which the parasite can swing within the radius equal to the length of those maxillae-fourth level. And that is sufficient for most of the lernaeopodids, but not for Schistobrachia. They are not dealt abundance of bulla; and second maxillae develop at their apices, long, digitiform processes which act as transfers for holding the parasite in position. But it isn't as simple as it seems. You see, the bulla isn't just a method of attachment. It's an organ which also acts as a means of exchange between the parasite and the host. We know that molecules as large as glucose can pass through it. It also aids in facilitating the circulation of the coelomic fluid of the copepod, which is necessary to assure a sufficient distribution of oxygen to the tissues of the copepod. So why does Schistobrachia reject it? What does it put in its place? Anything? I don't know, I don't think anybody does.

The ingenuity with which these animals act in complex form and function is inexhaustible. It has been said that the copepods represent a floating laboratory of evolution and parasitism. So they do. I don't think there is any group of parasites that represents such a wide range of adaptation to the parasitic way of life. At one side of that range, there are copepods such as Ergasilus, which have made very little concession, morphologically speaking, to parasitism. In fact, if it weren't for their superbly prehensile second antennae they would probably not be distinguished at all from the free-living animals. Their males do not become parasitic. At the other end of the scale, we have such par excellence parasitic genera as Xenocoeloma, which as an adult is only a bag of tissue, a coelomic cavity lined with host cells.

The adoption by the copepods of the parasitic way of life has freed them from the constraints which the unforgiving aquatic environment has placed on their morphology. Thus, mutations which come along in the course of a long phylogenetic history and which would prove fatal to a free-living copepod can be safely left. They accumulate, and their morphological expression sometimes results in imparting to the copepod a bizarre appearance.

Many parasitic copepods have fascinating, complicated sets of host-parasite relationships. I will mention here one, Phrixocephalus cincinnatus, which incidentally is a relative of Lernaeocera. As a tiny copepodid it attaches itself to the cornea of the fish, a flatfish, penetrates the cornea, swims across the anterior chamber of the eye, through the pupil, past the lens, down to the fundus of the eye, and there it pierces the retina and sticks it's head right into the choroid plexus which is wonderfully vascularized and provided with an enormous amount of food. So it grows. It feeds and it grows. Now, it could not complete its life cycle without emerging from the eye again to deposit its eggs into the external environment. How is it going to do that if it is fixed on its anterior end? It has to push its end out of the eye, backwards. Now, I have been once asked whether by any chance Phrixocephalus might have anal teeth! Well, I don't 
really know how it does it. But does it, it do! Except, sometimes when it misses the iris and hits the sclera it cannot get through it and it dies.

But I seem to have driven a little bit off the track. I intended to convey to my listeners the reason why I was so fascinated with copepods. Well, the reason, as it is usually in life, is a little bit more complicated. You see, other than the morphological and biological marvels of these animals, they also have a definite impact on fisheries... the fact which gives them very definite and measurable economic importance. For example, many, many years ago, almost half a century ago, when I worked in Scotland, I wrote an article in a bulletin prepared for national fishermen, in which I said that it was known that Lernaeocera causes its host, haddock, to lose weight. And I very quickly calculated, that if even one ounce of weight was lost by each infected haddock, in the year of 1955 the Scottish fisheries would have lost five thousand tons of fish, and that without catching one fish less.

Now, many years afterwards, ten years afterwards, working on the west coast of Canada, I worked with that rear-end pusher, with Phrixocephalus, and I found that by blinding the fish it reduces the population of its host by 10.7 percent. The blind fish can no longer catch prey, they are predatory, they die. In other words, they are decimated literally. In 1974, Sundness in Norway found that Lernaeocera kills off 6 percent of the cod population in Bergen Fijord.

And in 1968, the Soviet distant water fleet fishing in the area of Hawaii came across a stock of fish, Pentaceros richardsoni, which was sometimes known as long-spined boarfish... extremely valuable, unexploited, and they proceeded to fish it very vigorously. It was only when they unloaded the catch at home, they found that this fish was heavily parasitized by an unknown copepod parasite Pennella hawaiiensis. Eighty percent of the catch had to be condemned from human consumption. Thirty-six thousand, thirty-six thousand tons of fish were condemned. The economic losses were staggering. So, as you can see, we cannot, neglect this particular factor in our thinking about fishing in the sea, particularly in view of our diminution of marine resources.

To save you from the tedium of listening to a talking head for 45 minutes, I will now let the pictures, each one of which is supposed to be worth one thousand words, tell the rest of my story. So signing off, an old parasitologist, definitely not smelling like an orchid, and definitely also going to seed, once more wishes to express his gratitude to you for the privilege of speaking to you, and wishes that the parasites will be as good to you all as they have been to him. Thank you.

Editorial note: the airing of a video-taped version of the foregoing speech at the $78^{\text {th }}$ Annual Meeting of the American Society of Parasitologists was immediately followed by presentation of the video documentary Kabata: Evolution of a Scientist (see full citation above). 